\title{
Tōdaiji: A State Appropriation of Buddhism
}

\author{
Zhanyi Qi
}

Crean Lutheran Highschool, Irvine, California 92618, USA, johnny.altair1228@ gmail.com

\begin{abstract}
Buddhism, as one of the foreign religions in Japan, was introduced to Japan from China via the Korean Peninsula in the middle of the 6th century. After centuries of digestion, assimilation, reform and innovation, Japanese Buddhism finally successfully established a political position in the Shōmu Tennō era and formed state Buddhism. Tōdaiji, as a manifestation of Japanese state Buddhism entering its heyday, played an important role in ancient Japanese politics.
\end{abstract}

Keywords: State Buddhism, Tōdaiji, Ancient Japanese social system, Ancient Japanese diplomacy

\section{INTRODUCTION}

\subsection{General Background of Japanese Buddhism}

Buddhism is a religion founded in India in the fifth century B.C.E. by the historical figure Siddhartha Gautama who is more popularly known as the Buddha. During about the first to third centuries C.E., a system of Buddhist teaching focusing on "salvation for all", called Mahāyāna Buddhism, came to developing in East Asia and a series of kingdoms in Middle Asia. Buddhism was introduced to China around the second century A.D., and after a period of evolution, it was introduced to Japan via the Korean Peninsula in the sixth century. Different from Chinese Buddhism and Korean Peninsula Buddhism, Japanese state Buddhism was considered to have the main function of protecting the country from the very beginning. In the process of development, Buddhism influenced a series of Japanese political activities, including Taika Reformation, kentoshi, and ritsuryō-sei, and changed the ideology of the ruling class.

Taika reform was the most important reformation of ancient Japan. Under the ruling of Kōtoku Tennō, Japan went through a series of political reformations. Among them, adopting the "ritsuryō system" centralized power over the state to the Japanese court. "Ritsuryō system", a system using laws to establish absolute authority of the emperor and to regulate people, was an imported system from Tang. Brought back by kentoshi, who are envoys from Japan to Tang, this system strengthened the government's control of different regions, allowed no clan to own land anymore, and concentrated all power to the court. However, this newly developed system did not totally replace the old one. Conservatives in the country and accumulated hostility in the court all became holdbacks of the formation of a new social system. Buddhism teachings were continuously sent to Japan while ritsuryō-sei was adopted. For various reasons, Buddhism and the Japanese court had an inseparable relation. This interdependent relationship between politics and Buddhism reached its peak with the construction of the Tōdaiji and kokubunji system.

Tōdaiji, Grand Temple in the East (of Nara) in English, is the largest and longest-lasting royal Buddhist temple in Japanese history. It represents Japanese state Buddhism in a sense, and it also represents the Japanese court that advocated Buddhism during the Nara period (c. 710 794). As a religious site, Tōdaiji, which has actively participated in diplomatic activities, transnational Buddhist activities, and rituals of the ruling class, has a non-ignorable political role. It deliberately borrowed from the state temple of the Tang Dynasty, and also imitated the architectural style of the Tang Dynasty, but its transcendent fineness and supra-maximal size surprised everyone. Tōdaiji is a symbol of imperial power within Japan, a symbol of national stability and prosperity in the international community, and a symbol of innovation in ideology. This building and the ideas it represents have brought unprecedented changes to Japanese society.

\subsection{Tōdaiji}

Tōdaiji, the largest wooden temple in the world, once existed as a Japanese imperial Buddhist temple. It is also a government agency that manages all other temples in the country. It was built during the Shōmu Tennō period, and it took about 2.6 million workers to build it for 20 
years before it was completed. Its royal nature and huge structure symbolize the peak of Japanese state Buddhism. Japanese Buddhism was introduced from the Korean peninsula and became a dominant position in the court after being promoted by Shōtoku Taishi. Accompanying Buddhism into Japan is the law system from China and its systematic philosophy. In the fifty years after the Taika Reformation, Japan gradually promulgated various laws concerning currency circulation, official ranks, and household registration, and had a basically complete legal system during Shommu Tennō's regime. It evolved into a state religion in Shōmu Tennō and spread to all parts of the country. In history, in addition to religious influence, Tōdaiji also greatly influenced Japanese politics. Not only helped Japan gain recognition in diplomacy but also promoted the spread of new ideas in Japan and helped the country progress.

The tallest ancient pagoda in Japan now is the 55meter-high five-storied pagoda at Toji in Kyoto, but the destroyed seven-storied pagoda at Tōdaiji Temple was assumed to be over 100 meters high. According to the inscription of the Great Buddha Hall, two seven-level pagodas were built in the same period as the main hall was built. Among them, the western one is predicted to be over 100-meter-high. This is just a taste of Tōdaiji's colossus.

The Hall of Great Buddha is the main hall of the temple, also known as the Golden Hall. The current architecture was rebuilt in 1709, 57 meters wide and nearly 50 meters high. However, the size of the original architecture might be even greater.

"The architecture is approximately 40m high, $96 \mathrm{~m}$ wide, $56 \mathrm{~m}$ depth; The base is approximately $2.3 \mathrm{~m}$ high, long side $108 \mathrm{~m}$, short side $68 \mathrm{~m}$." [1]

The reconstructed Tōdaiji, after comparing with measures recorded on the inscription, has reduced the size of the original temple by $30 \%$, with its size of space still the largest ancient wooden structure in the world. The "Great Buddha" enshrined in the Hall of Great Buddha is Vairocana Buddha.

"The seated grand Buddha statue is approximately $18 \mathrm{~m}$ high; the face is $5.3 \mathrm{~m}$ high; mouth $1.2 \mathrm{~m}$ wide; ear $2.9 \mathrm{~m}$ high; hand $1.9 \mathrm{~m}$ high; used approximately 370 tons of copper and over 50 tons of gold." [1]

The state attaches great importance to this grand statue, it could be well-preserved until now because it used the finest raw materials, also, most of the used materials must come from the masses as the court, though prosperous, could not provide such a huge amount. Tōdaiji was usually only for the reception of eminent monks, royal family, court personnel, and envoys after its completion, but the number of people involved in the construction of the Great Buddha and the Hall of Great Buddha is estimated to exceed 2.6 million. Surprisingly, in the process of such a huge and tiring project, the people did not show any opposition. Compared with other buildings in the world, such as the Great Wall, built with the power of the whole state, the construction process of Tōdaiji seems to be too smooth. Plus Gyoki, a monk who is passionate about leading the people to build infrastructure, traveled around with his disciples to raise funds for the grand statue, the message of Tôdaiji's building was arguably known by most people around Nara. [2] In the Nara period, the urban structures surrounding the imperial palace has been formed, most people somehow participated in the construction of Tōdaiji or at least have seen it, especially the largest building, the Hall of Great Buddha.

The Buddhist ideology contained in casting the Great Buddha chosen by Shōmu-tennō (724-749) also coincides with the diplomatic and political role played by Tōdaiji, which was to establish a world without any barriers. In Buddhism, the Mahavairocana Buddha is the final manifestation of the Buddha. Buddhism claims that every Buddha has three manifestations, similar to the Christian trinity, called Trikaya, including nirmānakāya, sambhogakāya, and dharmakāya. What people have seen, Siddhartha Gautama, who once walked in the world as a real historical figure, is the nirmānakāya of Buddha, a living image the transformed into to save sentient beings. And the statue of the Great Buddha in Tōdaiji means to be dharmakāya which is the supreme manifestation of Buddha. The Buddha we ought to worship in this Buddha era, Śăkyamuni, his dharmakaya lives at the center of the Buddhist universe, protected by heavenly kings and other gods. It is the body of the reality itself, without specific, delimited form, wherein the Buddha is identified with the spiritually charged nature of everything that is. Casting dharmakaya Buddha in the royal temple not only expressed the Japanese court's pursuit of shaping a perfect world, demonstrating its admiration of Buddhism and diplomatic goodwill but also coincides with the Buddhist world described by Avatamsaka Sūtra in terms of ideology. Avatamsaka Sütra describes that a flower contains a Buddhist world, and each leaf in it symbolizes the existence of a Buddha. On the one hand, this teaching expands the Buddhist worldview, and on the other hand, it also establishes a strict, politically colored, hierarchical system for Buddhism. All Buddhas and their transformed images are under the control of Vairocana Buddha just like all regions, clans, as well as subjects, were under the control of the Tennō.

Tōdaiji not only has a gigantic structure but also contains extremely grand political ideals. The equal and perfect world symbolized by the grand statue Vairocana Buddha is what the Japanese court and the Japanese people urgently wanted. The largest temple and the most powerful Buddha in Buddhism, ordered to be built by Japan's supreme leader, represent the integration between politics and religion. The development of Buddhism in Japan was influenced by the political aspirations of the 
Japanese court, and the ideology of Buddhism also influenced the state. In the era of frequent disasters and chaotic relations between ujis in the court, the construction of such a huge Buddha statue shows the imperial court's desire to lead the country to a better place, but it also reflects the great difficulties Japanese court was facing to change the reality.

\section{POLITICAL USE OF TŌDAIJI}

\subsection{Solidify Regime}

Based on the archaeological findings of ancient Japanese documents, the way Buddhism entered Japan can be roughly divided into two forms: official transmission and unofficial transmission. According to the record of Fusō Ryakuki, Buddhism was brought to Japan by a Chinese official Sima Da unofficially in 552 . As for the time of official transmission, it is recorded in Nihon Shoki as 552 years and as 538 in Jōgū Shōtoku Hōō Teisetsu. Although the Suvarnaprabhasa Sūtra, a Sūtra that was not translated into Chinese until 702 was mentioned in Nihon Shoki, which means the demonstration of Buddhism's entering could be fabricated by the author, this evidence basically point out that Buddhism was introduced to Japan in the mid-sixth century during the Kinmei-tennō's (509-571) sovereignty. [3] The early spread of Buddhism after entering Japan was not undemanding. Japan's indigenous belief, Shinto belief, and the conflict of political groups with opposing interests within the imperial court have set up barriers suppressing the spread of Buddhism.

Shōtoku Taishi (c. 574 622) was who resolved these barriers and laid the foundation for the interspersing and development of Buddhism in Japan later. At the beginning of his administration, Japan suffered from both internal and external troubles. On the inside, the weak imperial family is almost losing its control over powerful clans; abroad, Sui China has risen as the most powerful entity in East Asia; wars on the Korean Peninsula have continued, and its relations with Japan have deteriorated sharply. All these incidents alerted Shōtoku Taishi to the urgency of innovation. This awareness, coupled with Buddhist significance in the court due to Soga clan's promotion, led to the promulgation of the Seventeenarticle constitution which integrates the ideas of Confucianism and Buddhism in the year of Suiko twelfth (604 A.D.). The second article clearly required people to worship Buddhism with loyalty. [4] Tenjukoku Shūchō Mandala, an embroidered relic made by Shotoku Taishi's concubine, has a written of "the earthly world is emptiness, only Buddha is true", which is in full compliance with the true teaching of Buddhism. Shotoku Taishi not only devoted himself to the study of Buddhist teachings but also interpreted Buddhist scriptures for the monarchs and ministers himself, these lectures were compiled in Sangyō Gisho. Tenjukoku Shūchō Mandala and Sangyō Gisho both prove Buddhism was well-known and finely comprehended in court. [2] He not only regarded Buddhism as the foundation of governing the country and educating people but also as a system of moral precepts, called on all subjects to worship Buddhism, which greatly promoted Buddhism in Japan. Shōtoku Taishi made Buddhist prayers for strength while facing difficulties in crusades and Soga no Umaku, as a leading authority in the court also vowed to worship Buddha in exchange for protection from Heavenly Kings before the battle. Based on all this evidence, Buddhism has become celebrated in the court and the philosophy that Buddhism is beneficial to the country was also established at the same time.

Upon the foundation laid by Shotoku Taishi, in the Taika Reform which took place in 645, Kōtoku-tennō (596-654) abolished bemin-sei that had long caused internal disharmony and adopted "ritsuryō system" which promotes the "one king over all" political ideology from Tang. In order to better adapt to ritsuryō-sei, the courtappointed Buddhist monk, Master Min who studied in the Sui and Tang Dynasties, as the country's kunihakase and laid the basic philosophy of governing with Buddhism. The series of actions of Taika reform solidified the significance of Buddhism in Japanese court in the Nara Period. [3]

After establishing a political system centered on Buddhism, Buddhism in the Japanese court has become the norm and its ideology became a consensus that the ruling class must understand. As more believers appeared, during Tenmu-tennō (673-686), the imperial court specially set up mitsuna to incorporate monks as intellectual individuals. After entering the Nara period, as the number of monks once again increased, Genshō-tennō (680-748) revised sogo to manage the monks in various temples. Tōdaiji's emergence, and the emergence of the entire Kokubunji system, is a manifestation of the rise of state Buddhism to the extreme. Tódaiji yoroku recorded that Shōmu Tennō holds multiple Buddhist ceremonies within a year, temples in the capital and all over the country were ordered to chant at certain time points. [4] Under influence of grand rituals, there were once three thousand people converted to Buddhism in a single month. Shōmu Tennō often held grand Buddhist rituals in the palace or Tōdaiji Temple. For each ritual, hundreds of monks were invited to recite Sūtras, ministers and other members of the royal family were also required to participate.

Buddhism has experienced the development of the Asuka period and the continuous promotion of many Tennō and has gained the support of the elite and the royal family. Under the influence of various Buddhist rituals and the emperor's belief in Buddhism, the royal family and the elites of society have been infiltrated by Buddhist ideas. The temples built for the imperial court and the more frequent rituals requiring the participation of elites 
are essential means of the court to further control certain groups. The government needs to rely on the elite to rule but does not want to repeat the same mistakes and decentralize power. The elites frequently met on religious occasions and were required to exercise religious thoughts. It can only use apolitical means to strengthen the relationship with the elites. In this process, certain religious activities became apparatus of the emperor and thus became political activities.

Buddhism had two positive influences on Japanese national politics. First, Buddhism has its own moral system compared to Shinto belief, the native religion of Japan. This means, while spreading Buddhist ideas, the Japanese court also spread a set of ethic codes. Such an approach can appease the people, teach them to act in an ethical way, and thus improve the living environment. Second, Buddhism has always been considered to have the function of protecting the country in Japan. The ruler believes that as long as it is pious enough, there will be heavenly power to protect the country from bad things. Speaking from a national level, attaching importance to Buddhism also increased people's confidence in the safety of the country.

Buddhist teachings drive people to pursue no this-life achievements but afterlife happiness, and this doctrine itself contains a set of value systems that promotes a "right" and "stable" life, thus, it is systematic and has a positive influence on the ruling class to complete the unification of ideology. The right speech, right livelihood, and right mindfulness contained in Mahayana's most important teaching the eightfold path, all require believers to pay attention to their words and deeds at all times to obtain ultimate salvation. At the same time, Buddhism introduces a rebirth system based on karma called metempsychosis, saying that all suffering in life is caused by wrong-doings of preexistences. Buddhist preachers claim that cursing, lewdness, greed, etc., summarizingly earthly self-indulgence, would lead to the painfulness of the next life. In the system of metempsychosis, entities keep rebirthing into multiple kinds of suffering beings until they pay off their debt and reach enlightenment, in other words, becoming Buddha. This system of belief, taken from a psychological perspective, makes full use of people's feelings of guilt and fear. It puts believers in a sense of indebtedness, claiming their suffering is the payback of preexistences, thus guiding people to be more productive and kind to reduce this inner tension. If accepting it, people would tend to reduce their pursuit of material satisfaction and turn to achieve emotional relaxation in order to prevent adding more karma into their lives.

In addition to teaching people, including civilians and the ruling class, to behave in a moral way, the idea of protecting the country from Buddhism is also promoting the political benefits of Buddhism.
Vicious-kings-ritual of reciting Suvarnaprabhasa Sütra, as a ritual frequently appears in Shoku-nihongi and Tódaiji yoroku, was one of the most common rituals in the Japanese court. Vicious-kings-rituals that invite over hundreds of monks were frequently held in the palace even before constructing Tōdaiji. The Tennō-given name of Tōdaiji is konkōmyō shitennō gokoku no tera, which is also deeply related to Suvarnaprabhasa Sütra (golden light most vicious kings Sūtra). [1] In the edict of constructing Tōdaiji issued in Tenpyo thirteenth, Shōmutennō ordered: "the name of this temple is golden light four heavenly kings state-protecting temple". Superficially speaking, the component "Golden Light" of Golden Light Four-heavenly Kings State Protecting Temple coincides with "Golden Light" of Golden Light Sutra, which means wisdom, and the name of fourheavenly kings instead of Buddha was used in the temple's name. There is no doubt that the most revered and noteworthy figure in Buddhism is Buddha, but the four heavenly kings are more in line with the functions of Buddhism promoted by the Japanese court. Thus, Shomu Tennō did not adopt the name of Buddha but the name of four heavenly kings to name this important temple.

In Buddhism, the four heavenly kings guard the four worlds in the Buddhist universe respectively, leading the deities absorbed from Indian mythology, Central Asian mythologies, and Chinese mythology as their servants to protect the inviolable majesty of Buddha, having the ability to remove all disasters and subdue any living beings even deities. Temples of the Tang Dynasty in the same period generally adopted the arrangement of seventemple-halls. The names of the architectures were Buddha Hall, Dharma Hall, Zen Hall, Canteen, Dormitory, Main Gate, Side Buddha Hall or Buddha Hall, Dharma Hall, Monk Hall, Kitchen\&Storeroom, Gate, Restroom, Bathroom. The system of the seven halls differs slightly depending on the region and environment, but the construction of the Heavenly-King-Hall was very rare, it was even more unlikely that the Heavenly Kings will be the mainly worshiped object of the temple. Although the worshipped Buddha may be different due to the different intentions built, worshipping Buddha and the scriptures is the norm of most Buddhist temples. The temples of the Korean peninsula such as Jogesa, Sinheungsa, Keumsansa, Beomeosa, etc., built between 650 and 800 years ago, also did not take the Heavenly kings as the main object. [5]

Shomu Tennō built and named Tōdaiji Temple, which represents state Buddhism and the court, as Konkōmyō shitennō gokoku no tera, chose Suvarnaprabhasa Sūtra over other Sūtras to enshrine, all because it represents the ideology of Buddhism stabilizes the state. After the completion of the Tódaiji, rituals to pray for the country will be held once every year including the most-viciousking ritual, nio ritual, etc., sometimes even multiple times a year. In Tenpyo ninth, Shōmu Tennō ordered to recite the wisdom Sūtra and the most-vicious-king Sūtra.; then 
Tenpyo tenth said all parts of the country, as well as the capital city to recite Suvarnaprabhasa Sūtra in three days, also in the edict of constructing Tōdaiji promulgated by Shōmu Tennō in the Tenpyo thirteenth, all Kokubunji temples, were required to recite Suvarnaprabhasa Sūtra at eighth every month, and recite Vimalakīrti-NirdeśaSütra fifteenth every month. In addition to the fixed-time rituals, Shoku-nihongi demonstrates a highly recognizable disaster-ritual order. After most recorded earthquakes, Tōdaiji will hold grand rituals to pray for blessings and the welfare of the state. These rituals are sponsored by the state, and the court often invites Japanese or foreign monks who have studied in the Sui and Tang dynasties to preside. Certain activities are held at a high frequency, certain scriptures are valued over others, and even the requirements for the level of the monk who presides in these rituals all express the importance of the Japanese court-attached state rituals. Needless to say, such special attention, just like emphasizing "four heavenly kings" in the name of Tōdaiji, is a manifestation of the belief that state Buddhism is conducive to rule.

To sum up, in the process of Japan's appropriation of Buddhism, many benefits of Buddhism for the political rule were slowly discovered. With such enlightenment, the Japanese court observantly incorporated Buddhism into the political system to implement political management by popularizing Buddhist thought. The relationship between Buddhism and people's safety is too illusory but it is not difficult to notice the significance of Buddhism in the stability of Japanese society in the Nara period.

\subsection{Diplomacy}

Building Tōdaiji and establishing the kokubunji system transmit friendly diplomatic messages to foreigners and partially fulfill the Japanese court's desire of becoming as powerful as Tang. In Japan's perception of neighboring countries, official diplomacy is based on the religious foundation of Buddhism in most cases. Tōdaiji, on the one hand, has gained international recognition with its gigantic structure and Tang rule architectural style. On the other hand, the construction process of Tōdaiji and the Buddhist rituals held is also a statement that symbolizes cultural tolerance.

King of Baekje began to enshrine Buddha statues to the Japanese court before the Asuka period; Goguryeo married its princess to the emperor of the Northern Wei Dynasty and prospered Buddhism to subject to the Northern Wei; Silla had built a large-scale state temple Bulkuksa in $535 \mathrm{AD}$, and attached the artificially excavated Buddhist grotto Seokkulam; during the period of Shotoku Taishi, the court also took Buddhism as one of the basic political tools; the envoys sent to the Sui Dynasty included monks from Japan; in the subsequent period of Nara, as the religious exchanges between Japan and the Tang became increasingly close and the ruling class gradually learns the Chinese language with their learning of ritsuryō, they have once again improved their understanding of Chinese-translated Sūtras. [2] In other words, within the possible diplomatic scope, ancient Japan could reach, all countries were influenced by Buddhist thought. As Buddhism existed as a significant diplomatic means during this period, Tōdaiji, as an expression of Buddhism, naturally became space diplomacy.

In particular, all countries had an influence on the development of Japanese state Buddhism, the Japanese court chose Tang culture as a base. This is because, in simple terms, Tang was the most powerful one. Tang has always been studied by Japan as a symbol of prosperity. Building state temples, architectural styles, and even ritual arrangements were all derived from Tang. Moreover, the entire Kokubunji system is not the first in Japan but originated from China. During the period of Wen emperor of Sui, Gaozong emperor of Tang, Wu Zetian, Zhongzong emperor of Tang, and Xuanzong emperor of Tang, China had all issued edicts to build Guofensi, which was the same as Kokubunji. Although other countries on the Korean peninsula, such as Baekje and Silla, have not found relics to prove a system as Kokubunji existed, these countries have invested in the construction of royal temples intended to protect the country. [5] Constructing state temples became a norm of East Asian countries around the Nara period. However, Japanese state Buddhism did not stop at imitating this norm but surpassed it.

Tang rule, as the most recognizable architectural style in Asia during that period, is highly recognizable. With the close connection with the Tang Dynasty, this style has become a representative of prosperity. Tôdaiji not only uses this highly recognizable and prestigious architectural manner but also has a gigantic structure that has exceeded all the wooden architectures that existed at that time, even those in Tang. Under the influence of the two, Tōdaiji is bound to be famous. Imagine a situation: monks from various countries found a temple that surpassed all temples in the Tang Dynasty in a small island country. Such news was spread by monks to different countries, and the monks who heard it would desire to go to Japan to appreciate Tōdaiji. Japan has shaped its image by building a state temple and also enhanced its diplomatic recognition.

Furthermore, Monks who had recognition in East Asia or those who are invited by the Japanese court will participate in or hold rituals at Tōdaiji, which shows that Tōdaiji Temple is in a sense an international Buddhist teaching exchange center. Any country could welcome outsiders, but it is miserable to accept the strange cultures that foreigners bring with them. During the construction of the Tōdaiji Temple, the Japanese imperial court not only accepted foreign monks but even allowed them to 
serve in the imperial court. Such an approach proves that Japan is becoming a more inclusive and open country under the dual influence of Buddhism and Tang culture. Gyoki who led monks to raise funds for the construction of the Buddha was a descendant of King Baekje; Fujiwara no Nakamaro who was for supervision was a descendant of the Baekje people in exile; Brahman monk Bodhisena who performed the inauguration of the Great Buddha Statue was from South Indian; the mantra preacher of the inauguration was the Tang monk Daoxan; Buddhist music player/singer was played by the monk Buttetsu from Champa, Vietnam. [5] At the opening ceremony of a state temple, Shōmu Tennō invited monks from foreign lands to preside over the inauguration and to perform Buddhist music from different countries. For the ruling class of any country, being able to accept another culture represents more possibilities for development. Acceptance of foreign cultures at the national level has also made the exchanges between the people and the outside world more frequent. For a period of time after Nara, the utensils, dining\&cooking tools, and partying arrangements used in Japan were all imported from foreign countries. In the records of the same period, there are also records of ordinary monks from the Korean peninsula teaching in other Kokubunjis. The Koubunji system, as a whole, has provided convenience to Japan in both official and non-official diplomacy. Japan's open foreign policy and frequent diplomatic activities during the Nara period were inseparable from Tōdaiji and Kokubunjis.

Again, to the international community, Tōdaiji was transcendence and a political statement. As known, Tōdaiji is an integration of Buddhism and state. What was reflected in this intentional imitation and transcendence of Tang architecture could be considered as a political statement that represents Japan's internal desire to become or even transcend the Tang. Japan's initiating of competition between itself and Tang was a self-test and a declaration of its power to other countries. After all, a country took surpassed Tang as a diplomatic statement must not be weak; a country that outcompeted the leading authority in a non-violent manner must also be civilized and prosperous.

\subsection{Transition of Ideology}

The reasons behind the Japanese imperial court's promotion of Buddhism in the Nara period were complicated, but from today's view, of the politics of this period, there seems to be a new system of ritsuryō-sei and Buddhism that challenges the old combination of beminsei and Shinto belief. Ritsuryō-sei and Buddhism seem to have an absolute advantage over the old system, but, this absolute advantage does not mean that Buddhism has completely changed the Japanese society based on Shinto belief, the competition between two sets of ideologies does not mean they could not achieve co-existence.
Apart from uniting the court, pacifying people's livelihood from a psychological perspective, and increasing diplomatic recognition, the appropriation of Buddhism also reflects the turn of the political ideology of the Japanese imperial court. Before Kōtoku Tennō brought greater centralization and enhanced the power of the imperial court, which was based on the governmental structure of Tang, the bemin system has dominated for centuries. In the previous Japanese rule, Yamato sovereignty established the bemin system based on uji, the most basic unit of the bemin system, similar to a family. The uji were not just a group of blood relatives who were formed by a natural occurrence, but a group of blood relatives who swore vassalage to and were obliged to serve the great king. The uji in the capital and local provinces established a relationship with the great king of vassalage and service, and on this premise, they were given the license to take up fixed political standings and government posts/duties along with the right to make them hereditary. Further, the uji were given kabane according to differences in their status by birth and political rank of government content of duty, and it was permitted for them to own subordinates such as the bemin (people who belong to the clan). Bemin system affirmed certain ujis' contribution to the sovereignty, optimized the relationship between the imperial court and the powerful ujis by appropriately decentralizing power to ujis that were willing to help the Yamato court. However, over time, the relationship between the court and the ujis that were granted kabane gradually weakened because of the transmission of a leading power.

There seems to be no historical conflict between Shinto belief and Buddhism in Japan, but the ideological conflict between the two surprisingly occurred in a political way. The origin of Shinto belief is similar to animism, and the fearsome elements in nature with extraordinary abilities are worshiped as deities. In the Yayoi era (c. 300B.C.-300A.D.), when the ujis were not unified under a sovereign yet, each uji has its own unique deity and there was no comparison between the strong and the weak between the worshiped deities. Kojiki, which described Amaterasu Omikami as the supreme god to dominate all things of Japan, was ordered to be written between 711 and 712 by Tennō, apparently for strengthening the legitimacy of imperial despotism. [2] The story recorded in this book distinguishes the Yamato clan from other clans, focuses on the Yamato clan itself only, but does not explain the relationship among other worshiped deities. In other words, Shinto belief has not established any hierarchy, nor has it established a social system that encompasses all the ujis. Under the influence of certain ideologies, the relationship among the various ujis in the bemin system was always in a state of confusion.

Moreover, Shinto belief did not create its own values, but only emphasized worshiping, which made it impossible for Japanese society to find moral models or 
learn ethics from Shinto. Buddhism, unlike Shinto belief, had a complete system when it was officially introduced to Japan. It established a Buddha-centered wellcontrolled universe, a perfect afterlife world, a behavior standard Eightfold path, and a value system of "four noble truths". Images of Buddhas and Bodhisattvas that are more human-like, behavior standards that can be imitated, and the world after death promoted by Buddhism are in sharp contrast to the chaotic Shinto system. In Shinto, the natural elements that are worshiped as deities cannot be manipulated by people. No matter how many things people tribute or how piously worshiped, the natural disasters that should occur will still occur. In Buddhism, doing the right thing can get people a better next life in the metempsychosis system, or even directly get out of the system, becoming a Buddha or Bodhisattva. Although it is impossible to prove the existence of the post-mortem world, putting trust in Buddhism seems to be more certain than in Shinto belief. At least in a limited lifetime, people don't need to see their piety and commitment being defied, seemingly betrayed by deities without giving any reason. Many deities of Shinto were understood as the cause of disasters in the world, while Buddhism is used to cast away them.

Although Shinto belief has not been replaced by Buddhism, he is in a very embarrassing situation: he can neither withdraw from the competition nor gain an advantage. During the heyday of Buddhism, Master Gyoki chose to integrate with Shintoism in the way of honji suijaku to further expand the influence of Buddhism in Japan. This choice not only further strengthens Buddhism, but also provides the possibility for Shintoism to develop. The honji suijaku theory claims that the gods in Shinto belief are the incarnations of figures in Buddhism, so Shinto does not conflict with Buddhism. [6-9] This move caused the originally unorganized deities in Shinto belief to be put into the Buddhist system. Corresponding to the arranged Buddhas, deities finally formed their own systems. This system, due to the absolute authority of the Yamato Clan in Japan, has also become a tool for the Japanese court to establish its authority. The Japanese imperial court merged Supreme Buddha, Dainichi, and deity, Amaterasu, which symbolizes the Japanese imperial family, into one image, thinking that the Great Buddha enshrined in Tōdaiji and the Amaterasu enshrined in Ise Shrine are actually one. Kojiki, which was written in 712, included the systematic Shinto belief for the first time, which is the root of Shintoism as we see it now.

In summary, although affirmatively clarified an authority, Shinto belief does not produce a complete system, this basic logic conforms to the logic of the bemin system and slavery society; Buddhism includes codes of ethics, specific regulations for behavior, and has a centralized world, which are characteristics consistent with ritsuryō-sei and feudal society. The huge difference between the two ideologies makes them seem to have formed an opposing situation during the Nara period, but in fact, Buddhism, as a foreign religion, cannot replace Shinto as the foundation of blood relationship. The two finally reached a delicate symbiotic relationship: Shinto belief continued to exist on behalf of the blood relationship, absorbed the logical hierarchy of Buddhism and ritsuryōsei to form Shintoism we see today, and Buddhism existed as a necessary component of the superstructure.

\section{CONCLUSION}

The original intention of Tōdaiji Temple was for establishing an official venue for Buddhism and pray for the welfare of the country, in other words, for religious purposes. However, in the process of its construction, Japan's diplomacy developed rapidly and the social system changed dramatically, making Tōdaiji not only exist as a religious site but also politically useful. Because most East Asian countries adopted Mahayana Buddhism, the usage of Buddhism in protecting national stability is widely recognized, so the establishment of large-scale Buddhist temples was considered to be a manifestation of national stability. As Buddhism was legible in Asian international politics, Tōdaiji has hosted monks from various Asian countries and has become a site for international Buddhist exchanges in Asia, and then, with the help of traveling monks and ambassadors, Japan expanded its diplomatic influence. On the basis of Buddhism in the ruling class established by Shotoku Taishi, promoting Buddhism helped rulers to consolidate their authority and to unite the elite. The ruler established the Kokubunji system headed by Tōdaiji in order to disseminate suitable ideas among people to strengthen the control over them, so that ritsuryōsei from Tang could be correctly implemented and to further strengthen the country. Moreover, building Tōdaiji is a manifestation of the transition of political ideals. The ruler hoped to obtain the stability of the country through Buddhism, at the same time, to solidify the new system through values conveyed by Buddhism, challenge the old system of bemin plus Shintoism system with the new system of ritsuryōsei plus Buddhism. The turn from Shinto belief to Shintoism and the establishment of the political hierarchy of the whole country all proved that Japanese society had accepted the idea of establishing a legal system at that time.

\section{REFERENCES}

[1]. Bukkyo University Library. (1851) Tankaku sosho Shingaichitsu - Tōdaiji Yoroku. https://bird.bukkyou.ac.jp/collections/todaijiyorokusoshoshingai-02/

[2]. Tsukamoto Z., Hirano U. (1974) Buddhism in the Asuka-Nara Period. Eastern Buddhist Society NEW SERIES Vol. 7, pp. 19-36.

[3]. Nara National Museum National Treasure Collection Databse. (2015) Nihon Shoki (An ancient history of 
Japan).

https://www.narahaku.go.jp/english/collection/1190

$-0 . h t m l$

[4]. Donald P. (1969) Kojiki: Translated with and Introduction. Princeton University Press, Princeton \& University of Tokyo Press, Tokyo.

[5]. Yong W. (2012) Japanese Culture. Higher Education Press, Beijing.

[6]. Wu Chunyan. (2021)Localization of Buddhism in Japan. Academic Journal of Zhongzhou Vol.1, pp. $170-173$

[7]. Waseda University Library. (2021) Shoku-nihongi (Ancient history of Japan continued). https://archive.wul.waseda.ac.jp/kosho/ri05/ri05_02 450/ri05_02450_0016/

[8]. The Imperial Household Agency. (2021) Shoso-in Treasures. https://shosoin.kunaicho.go.jp/enUS/about/treasure

[9]. Kazuhiko Y. (2003) Revisioning Religion in Ancient Japan. Japanese Journal of Religious Studies Vol. 30 No. $1 / 2$, pp. $1-26$. 